Revista Iberoamericana. Vol. LXIII, Núm. 180, Julio-Setiembre 1997; 419-435

\title{
METAFICCIÓN Y PRODUCTIVIDAD \\ EN JOSÉ DONOSO
}

\author{
POR \\ Catalina Gaspar \\ Universidad Central de Venezuela
}

\section{CASA DE CAMPO: caOS y CARnAval}

Desde tiempos inmemoriales el hombre busca aprehender en los textos ficticios imágenes de su tránsito por el mundo, de su acontecer como individuo y como colectivo. Percibe que en la fabulación se encuentran a menudo las "claves"-la "verdad", el "secreto"- de aquello que otros discursos no alcanzan a plasmar, intenta tal vez reconocerse en la urdimbre de signos que teje la escritura, y al participar de la experiencia literaria ella se ofrece como un espacio de diálogo, de confrontación o de afirmación: espacio privilegiado para el despliegue creador de la significación. Frente al caos de la experiencia, la ficción quiso erigirse en un orden, en revelación de la trama secreta que organiza nuestra realidad:

La vida real fluye y no se detiene, es inconmensurable, un caos en el que cada historia se mezcla con todas las historias y por lo mismo no empieza ni termina jamás. La vida de la ficción es un simulacro en el que aquel vertiginoso desorden se vuelve orden: organización, causa y efecto, fin y principio. (...) Las novelas tienen principio y fin y, aún en las más informes y espasmódicas, la vida adopta un sentido que podemos percibir porque ellas nos ofrecen una perspectiva que la vida verdadera, en la que estamos inmersos, siempre nos niega (Vargas Llosa 9).

Pero si bien la novela realista, e inclusive novelas metaficcionales como Cien años de soledad, Los pies de barro o Historia de Mayta, entre muchas otras, develan su complejidad dentro de un orden totalizador que re-crea nuestra experiencia, la metaficción productiva, ${ }^{1}$ de la cual El obsceno pájaro de la noche se torna paradigmática, es en sí misma un sistema caótico que desentroniza la verdad y el orden como fundamentos textuales, y con ellos toda pretensión de unidad del sujeto de la enunciación, de la estructura temporo-espacial, del acontecer y de las figuras narrativas. Es, justamente, como productividad, un texto que "fluye y no se detiene, es inconmensurable, un caos en el que cada historia se mezcla con todas las historias y por lo mismo no empieza ni termina jamás”.

${ }^{\prime}$ La metaficción productiva es una categoría de la narrativa metaficcional que proponemos como diferenciada de la mimesis del proceso (Hutcheon) y de la mise en abyme especular (Dällenbach). Ver mi libro Escritura y metaficción. 
Tal vez, desde esta perspectiva, paradójicamente, la metaficción productiva, en tanto sistema caótico, realice la vieja aspiración de la mimesis: ser la realidad misma: "A mimetic fiction text masquerades as a copy of the world but is not. Metafiction reveals, on the other hand, how the emergent chaos of a text and of the world are one" (Stoicheff 94). Y es el concepto de entropía, que ha sido trabajado en múltiples campos del "saber", y ha dado lugar en la posmodernidad al desarrollo de una teoría del caos en el marco mismo del problema de la "legitimación del saber" (Lyotard 107-108), el que revela, en su estrecha relación con la teoría de la información, su vinculación con el relato metaficcional, en tanto éste constituye un esfuerzo por escapar de la información que caracteriza al relato mimético.

En el ámbito de la ficción, el caos y la entropía han sido permanentes fuentes de creación estética: en su carácter metafórico - los laberintos borgeanos- o como generadores de las tensiones que dinamizan el espacio textual —orden, causalidad, entropía - al tiempo que son "tematizados" en él. Ejemplo de ello son los relatos "Entropía" y "La forma de la Tierra" del volumen Rajatabla de Britto García, y especialmente su novela Abrapalabra, en donde los discursos que tejen la urdimbre del universo textual generan, en su transgredir todos los límites, sucesivas oleadas entrópicas "disociando el tejido último del universo", el cual, abolida la cadena de causas-efectos, se precipita en la nada (Gaspar, El universo V).

En The Chaos of Metafiction, Stoicheff plantea que la metaficción narrativa posee características comunes a las localizadas en lo que la ciencia actual denomina caos, entre ellas la autorreflexividad: momento autorreflexivo en el que se interroga, ya no al mundo ontológico o fenomenológico, sino a la transmisión de significancia en el margen que separa el texto y el mundo:

Post-Saussurian investigation has revealed how that margin is not an unproblematic prism of decodin but a highly chaotic site where the indeterminacy of language proliferates (86).

El lugar de la contigüidad entre el discurso de la "realidad" y el discurso literario se revela como un espacio caótico, donde la disonancia entre ambos discursos engendra significaciones. Disonancia, negatividad, que es fundamental en la productividad del texto, que excede las dicotomías realidad/ficción, verosimilitud/inverosimilitud, para proponerse como un discurso diferenciado, que no se conforma con oponer una visión del mundo a otra, así como tampoco con la negación de toda realidad en procura de su verosimilitud para ensimismarse.

La "negatividad" es un movimiento de no-identidad que destruye la ley natural, el “orden”, para hacer del carnaval, de la relativización jocosa, de la inversión, de la deconstrucción, del caos, de la ambigüedad, principios generadores del relato. Es por ello que "metafiction is an investigation of the chaos of meaning's production" (Stoicheff 87) y, como evidencia Eco, la relación de entropía e información se expresa en la ambigüedad discursiva que podría situar al texto en el umbral del caos asignificante, y precisa de la "ambigüedad productiva".

Tensión entre orden y caos que narran metaficcionalmente textos como El obsceno pájaro de la noche, Casa de campo, Abrapalabra y numerosos relatos de Borges, cuya ambigüedad productiva en la semiosis ilimitada de sus signos, en su descentramiento especular, formula una estética de la ficción y del lector, exigiendo de éste una inusual actividad decodificadora y creadora, porque para el lector "The metafictional 'narrative of chaos' produces a metafictional understanding of a metafictional or chaotic world" (Stoicheff 95). 
La autoconciencia de la metaficción productiva como sistema caótico y altamente complejo, que obliga a la recodificación en su tramado con los interpretantes del lector, hace del discurso el espacio de la especularidad, el artificio, el dialogismo, la alteridad, el descentramiento, la ambigüedad, el caos, categorías discursivas que trazan las tensiones que dinamizan la generación de significancia, y dibujan una poética de la ficción literaria desde su narrarse como carnaval y rizoma.

La metaficción narrativa es también, para nosotros, una concepción carnavalizada del texto, en tanto la metaficción, como la vida en el carnaval, es "ella misma la que juega e interpreta" (Bajtín 13). En el ámbito de la productividad textual, como en el del carnaval, la literatura - la vida - se interpreta a sí misma: el juego de la puesta en escena no es "espectáculo" sobre la realidad, "fiesta oficial" que consagra la verdad, lo monológico, lo centrado. Es, como El obsceno pájaro de la noche y Casa de campo, parodia -ironía, negatividad- que despliega un mundo al revés, fluctuante, en devenir, en constante permutación: un discurso cuyo movimiento "rompe las leyes del lenguaje censurado por la gramática y la semántica, y con ese mismo movimiento es una impugnación social y política" (Kristeva, Semiótica 189).

La metaficción productiva es el ámbito privilegiado donde se realizan los conflictos de la producción discursiva, que crean un espacio otro para la experiencia humana en la desnaturalización de los principios "naturales" de la vida social y de los discursos en ella engendrados. Aventura que parece ser la central en el posmodernismo cultural:

Defino el posmodernismo cultural como la comprensión de que los componentes de la experiencia humana que fueron siempre considerados como esenciales e invariables no son hechos naturales de la vida sino construcciones sociales (Hayles 327).

En la metaficción productiva el carnaval es la puesta en escena de la conflictividad discursiva, de las tensiones ideológicas y estéticas que se ponen en juego. De tal manera que si el espejo del realismo quería reflejar ya no "la realidad" sino constructos, invenciones, ideologías, discursos, la relación realidad y ficción, texto y contexto, se problematiza. En lugar de querer expresar la ley natural, aun para refutarla, como un discurso segundo, la metaficción productiva pone en escena su generación como un corte, una hendidura, una grieta en el seno del discurso de realidad. Ya no se trataría simplemente de la transformación de los materiales preexistentes, que constituirían lo que Lewis (3-31) denominó la referencialidad anterior del discurso, sino de la interiorización del conflicto entre discursos, de la puesta en escena de la interrogación, de la recusación, del diálogo y la ambivalencia bajtianas, ya que:

El libro no es la apariencia tomada por una realidad exterior que él escondería al mostrarla: su realidad se encuentra toda en el conflicto que lo anima y que, con exclusión de cualquier otra cosa, le concede su condición (Macherey 38-39).

Desde esta perspectiva comprendemos que en la metaficción productiva el texto es en su totalidad un metatexto que narra la negatividad sobre la cual se asienta, la ausencia que lo impulsa y sus procesos generadores en la alteridad realidad/ficción. Prismáticamente, en plurales mises en abyme que se interrogan entre sí, la escritura es el espacio donde se escenifica su propia generación. 
Discurso sobre el discurso, ficción sobre la ficción, la metaficción productiva es una extraordinaria puesta en escena de la pasión deconstructiva que la recorre. En la respiración del texto, en el cuerpo de su escritura, se inscriben otras voces, también desentronizadoras, también autorreflexivas:

¿Qué civilización, en apariencia, ha sido, más que la nuestra, respetuosa del discurso? ¿Dónde se le ha honrado mejor? ¿Dónde aparece más radicalmente liberado de sus coacciones y universalizado? Ahora bien, me parece que bajo esta aparente veneración del discurso, bajo esta aparente logofilia, se oculta una especie de temor. Todo pasa como si prohibiciones, barreras, umbrales, límites, se dispusieran de manera que se domine, al menos en parte, la gran proliferación del discurso, de manera que su riqueza se aligere de la parte más peligrosa y que su desorden se organice según figuras que esquivan lo más incontrolable; todo pasa como si se hubiera querido borrar hasta las marcas de su irrupción en los juegos del pensamiento y de la lengua. Hay sin duda en nuestra sociedad (...) una profunda logofilia, una especie de sordo temor contra esos acontecimientos, contra la aparición de esos enunciados, contra lo que puede haber allí de violento, de discontinuo, de batallador, y también de desorden y peligroso, contra ese gran murmullo incesante y desordenado del discurso (Foucault, El orden del discurso 42).

Casa de campo es un texto que desafia desde su praxis discursiva el discurso del poder y el poder en el discurso, preocupaciones constantes en la narrativa donosiana manifiestas en diferentes ópticas y realizaciones ficcionales-El jardín de al lado y La desesperanza. Como en El obsceno pájaro de la noche, el mundo representado se construye en la oposición entre un adentro y un afuera. El adentro es la Casa de los Ventura, espacio laberíntico, en el cual los "padres" han instituido todas las coacciones del poder mediante el escamoteo y disfrazamiento de la "verdad", la artificialidad y la represión, construyendo un orden de jerarquías, normas y privilegios en cuya pirámide se encuentran los grandes, y cuyos instrumentos, los sirvientes y lacayos, controlan el universo representado por los treinta y tres niños y garantizan la exclusión del afuera. En el "afuera" se encuentran los nativos, quienes constituyen un discurso periférico al discurso de los Ventura y, excluidos por él, habitan, como la Peta Ponce, en los galpones, en el "revés" de la fachada y son quienes, al igual que la Peta Ponce y Humberto Peñaloza, sostienen el poder, al ser ya no sólo sus "testigos" sino también quienes le otorgan con su trabajo substrato material.

Entre la "partida" y el "regreso" de los Ventura padres, travesía del poder a la cual corresponde la disposición estructural de la novela en dos partes, se narran diversos proyectos para instituir "otros" discursos: la pugna entre el mayordomo y su ayudante, Juan Pérez; la rebelión de Adriano Gomarra y Wenceslao; el del "piano nobile", y el de los "extranjeros" apoyados por Malvina. Pertenecientes a la última escala del poder, y configurados por él e identificados con sus principios a la vez que sus víctimas, son los primos quienes, a la partida de los padres, desencadenan la insurrección y hacen aflorar el caos que anidaba - como en $E l$ obsceno pájaro de la noche - en el discurso del poder, y que amenaza destruirlo con el mal, lo obsceno, lo abyecto y la locura; caos que desencadenará una feroz represión.

La novela ha sido leída como alegoría del poder, cuyo referente histórico serían los sucesos acaecidos a raíz del golpe militar contra el gobierno de Salvador Allende. En este sentido, Casa de campo sería la "novela testimonio", la "gran novela social de Chile" que en 
una oportunidad requirió de Donoso Pablo Neruda, reclamo que en El jardín de al lado dirige a Julio su esposa Gloria: "Escribe la gran novela del golpe, Julio. Si estuvieras comprometido y convencido como Carlos, entonces podrías escribir la gran novela chilena" (Donoso, El jardín de al lado 167). Problemática ética y estética que en Casa de campo se manifiesta en las tensiones interiores del discurso, que internaliza el referente político-social y lo nombra desde su "irrealización": la alegoría se teje sólo desde la ficción carnavalizada que produce el discurso textual, porque como plantea GutiérrezMouat, la propuesta del texto es la del carnaval y éste, "al convertirse en mundo, invalida todo punto de referencia externo a la vez que instituye la primacía de la ficción” (223).

Así, más que del enfrentamiento del discurso del poder al poder del discurso, se trataría de la puesta en escena en la productividad textual de su ambivalencia discursiva, que involucra la tensión orden/caos tanto en la alegoría del poder como en la ironización del poder autorial, interrogando las coacciones y las condiciones de "verdad" del propio discurso.

Tras la salida de los padres al "afuera" de la Casa, en el "adentro" los treinta y tres primos escenificarán la generación de otra producción significativa, la del discurso transgresor que se enfrenta a los criados y lacayos, quienes querrán, como sustitutos de los padres, mantener el orden. La infracción desencadena el caos, el discurso de lo otro que emergerá en situaciones límites: el mal, la locura, la antropofagia. Emergencia de lo otro que sólo será posible cuando se desentroniza a los padres del discurso, cuando éstos abandonan la escena textual y otros sujetos de enunciación se apoderan de ella. Parecería, de esta manera, que lo que busca suprimirse en las reiteradas escenificaciones de la represión física y psicológica que es infringida a los niños, y en el encierro de Adriano, es el caos de la productividad textual, la emergencia del logos de la imaginación, de su azar y su violencia, para anular su diferencia, someterla al orden de "lo mismo" mediante la "voluntad de verdad", discurso enmascarador que aspira a "correr el tupido velo" sobre aquello que acecha su hegemonía y su univocidad, su "ley".

Voluntad de verdad que se escenifica en el juego de "La Marquesa Salió a Las Cinco", "esa máscara que encubría la mascarada" (Casa de campo 149), ficción dentro de la ficción que pone en escena irónicamente al discurso realista en sus procedimientos de control, que pretenden escoger los sujetos que pueden hablar y decidir la veracidad o falsedad de los acontecimientos. Pero la ficción de "La Marquesa Salió a Las Cinco" se carnavalizay desborda no sólo los límites trazados por el discurso del poder sino también, metatextualmente, los límites de la ficción dentro de la ficción.

El artificio, lo imaginario, lo no-verosímil, dejarán de ser una alteridad frente al discurso del poder para tornarse productividad significante, que configurará el discurso en un caos imaginario que, como la selva de zapallos de El obsceno pájaro de la noche, tomará el afuera: las gramíneas que "se habían apoderado de toda la llanura, de horizonte a horizonte" (293), se apoderarán del mundo representado. Las dicotomías afuera/adentro, orden/caos, quedan abolidas en el acto simbólico en el cual se desclavan las lanzas. Se pierden los límites que trazaran los "padres" del discurso, y las gramíneas - y con ellas los nativos - invaden todos los ámbitos:

Borrado el límite de la reja (...) las gramíneas habían logrado fundir la extensión del paisaje con lo que antes fuera el civilizado parque. Crecían ahora irreprimibles, fantásticas en medio de los senderos y los prados (290). 
La productividad textual refuta, una vez más, la estaticidad del libro en la Biblioteca de la Casa de los Ventura, en la cual, como en la de Jerónimo, "detrás de esos miles de lomos de soberbias pastas no existía ni una sola letra de molde" (33). Apariencia irónica que es también, desde nuestra perspectiva, la de la figura hegemónica, omnipresente y omnisciente cuya voz narrativa se identifica en Casa de campo como "substituto autorial".

Como ha sido planteado por la crítica de la novela y el propio "narrautor" se ocupa de explicitar, su presencia busca poner de relieve el carácter artificial, inventado, de "su" historia, en oposición a la supresión del narrador representado en la ficción realista, con la cual se aspira a crear la ilusión de natural fluidez del relato y, con ello, enfatizar su verosimilitud. En esta orientación, Carlos Cerda plantea lo siguiente:

El rol omnisciente, omnipresente y omnipotente del narrador en Casa de campo, que constituye una abierta irrupción del autor en el relato, es perfectamente concordante con la estrategia narrativa de Donoso, orientada a desechar una estética de la ilusión, basada en recursos imitativos o miméticos. En lugar del recurso comentado (simulación de un texto sin autor para aumentar la verosimilitud de lo narrado) Donoso asume el papel del narrador; no sólo se introduce en el relato, sino que nos muestra cómo lo va configurando, con vistas a recordarnos siempre que aquello que leemos es una ficción, una irrealidad, un texto novelesco (Cerda 31).

El discurso del narrador pretende el absoluto poder sobre el mundo del cual se dice creador, y desde sus primeros enunciados autorrefiere a la figura del autor empírico de la novela que leemos:

Quiero que este capítulo de mi historia retroceda en el tiempo para analizar las actitudes de esta familia que estoy inventando - y de paso explicármela a mí mismo a medida que la construyo-, lo que echará luz tanto sobre aquello que sucedió en el día mismo de la partida de los Ventura como sobre los horrores que sucedieron después. Mi mano tiembla al escribir "horrores", porque según las reglas estaría anticipándome a los efectos que deseo producir (54).

El narrador se propone a sí mismo como el escritor de la novela que leemos, escritura que se plantea como simultánea a la invención de la historia. La proposición de omnipotencia y omnisciencia sobre la ficción es la de un titiritero que mueve los hilos de sus personajes-títeres. $\mathrm{Y}$ en efecto, en Casa de campo la noción misma de la puesta en escena metatextual es, como en Hamlet, figuratizada, y la mise en abyme textual se muestra como mise en abyme prospectiva y generalizadora (Dällenbach 76-78) desde el inicio del relato, en cuya primera página, como si de una pieza teatral se tratara, se exponen los nombres, genealogía y edad de los "personajes" que aparecerán acto seguido en escena. Al abrirse el telón y asumir el narrador la enunciación del relato, encontramos que lo que se escenifica es la generación de un universo ficticio, que se propone como absoluto artificio, urdido en el despliegue de la escritura-narración del "narrautor".

Nos encontramos con una mise en abyme de la enunciación en la "presentificación" del productor del relato (Dällenbach 95), la cual ha sustentado una visión crítica en torno a la novela que entiende al narrador como "presentificación" del autor empírico, el cual en mise en abyme estaria "representado" en el discurso en el proceso de escribirlo-narrarlo, actos que darán origen 
a la novela que leemos: la novela que el "narrautor" escribe es Casa de campo; se trataría de la mimesis del proceso de la cual habla Hutcheon. Desde nuestra perspectiva, en cambio, los aspectos textuales señalados, que configurarían la mise en abyme de la enunciación, son parodiados y desmitificados en Casa de campo para proponer, en lugar de una mise en abyme de la enunciación, la productividad textual que la desentroniza, y hace de la novela una extraordinaria propuesta de otra noción de la narrativa metaficcional, que hemos denominado metaficción productiva.

La absoluta autonomía del universo ficticio que el "narrautor" proclama es refutada justamente por la intromisión de lo extradiegético en lo diegético. Si bien la ilusión de realidad es destruida por el narrador, que enfatiza permanentemente la artificialidad, el carácter constructivo del universo narrado, el mismo narrador introduce una nueva falacia: la pertenencia del discurso ficticio a la voluntad de un autor que lo construye y puede explicárselo a sí mismo y al lector, erigiendo con ello "una instancia trascendental, el Autor, asumiendo la totalidad del enunciado de la novela" (Kristeva, El texto 64).

Desde esta perspectiva, Casa de campo no enfrentaría el discurso del poder al poder del discurso; por el contrario, dramatizaría, en la problemática del poder que se escenifica en el mundo representado, las tensiones por la productividad significante del discurso, que ha de combatir la univocidad y omnipotencia del poder "autorial" como "centro" discursivo, como "sujeto" de la escritura.

En efecto, el "narrautor" parodia en su discurso el juego de poder que se lleva a cabo en la historia de la cual se afirma creador, escritor y único productor. Es el "padre" quien, al igual que los "padres" Ventura, ejerce todas las coacciones del discurso: decide los sujetos que tendrán voz, qué aspectos de su historia dar a conocer al lector, qué mostrar y qué ocultar. Establece las líneas de demarcación, de exclusión, de verdad, las líneas del "decir" y del "silencio". Pero ironiza también en torno a su propio poder:

PERO NO. Es preferible no dar el texto que prometí en el párrafo anterior: la experiencia del dolor, cuando es de gran intensidad y significación, no puede ser reemplazada por la fantasía (...) En versiones anteriores de esta novela, aún en las galeradas, venía en este sitio una extensa sección que no era otra cosa que el monólogo de Arabela (...) La modestia me aconseja, más bien, correr un tupido velo sobre estos pormenores, ya que es imposible reproducir esos horrores para quien no los ha vivido, y además quizás sólo sean rumores: ya se sabe lo mentirosos que son los niños (Casa de campo 345-346, énfasis mío).

En este enunciado se juegan todas las coacciones y se desenmascaran en la propia enunciación: es la productividad significante del texto la que contradice el enunciado "autorial": el artificio que el narrador proclama es también la farsa del trompe l'oeil, y de "La Marquesa Salió a Las Cinco", donde mentira y verdad pierden sus límites, y los niños no son sujetos mentirosos como lo afirma el enunciado "verosimilizador" del narrador que irónicamente el texto deconstruye: son sujetos de la enunciación de un otro discurso, que enmascara y desenmascara su propia afirmación, y que la enfrenta, en sus tensiones internas, al juego de poder que es todo discurso. En él, la opción de "correr el tupido velo", de recubrir -como en El obsceno pájaro de la noche - con el "poncho" silenciador lo "que realmente aconteció" más allá de su representación en el enunciado, se revela en los silencios y negatividades que erige el juego desideologizador de la escritura. 
Se trataría así de un aparente desdoblamiento especular: lo metadiegético se torna diegético, pero la diégesis - la narración - se desdobla a su vez en un narrador extradiegético, que permanece fuera del mundo representado y se enuncia a sí mismo como titiritero de sus personajes y situaciones, invenciones sin vida propia. Sin embargo, el narrador interrumpe, en una metalepsis continua, el fluir del relato, el cual acota, explica y anuncia en permanentes digresiones, mises en abyme anticipatorias, y otros recursos mediante los cuales su ser "ajeno" al universo construido se transgrede. Transgresión que llega a su nivel extremo en la metalepsis que significa el acto de lectura, al interior del texto, del narrador a uno de sus personajes, a Silvestre Ventura. Esta metalepsis pone de relieve el intertexto narrativo, permanentemente explicitado por el narrador, que enfrenta lenguajes y códigos diferenciados.

Pero también muestra, en su carácter contradictorio, las tensiones que genera la presencia figuratizadadel narradory su proclamada representación del "autor", refutando la omnipotencia. Como en El obsceno pájaro de la noche, los personajes manejados como títeres, tiranizados por éste, adquieren autonomía ficcional, y enfrentan a su "creador".

Para nosotros, Casa de campo pone de manifiesto lo que hemos llamado la falacia metatextual: la presencia de lo metadiegético en lo diegético no puede ser entendida como la "explicación del relato", en un nivel de lectura que sigue concibiendo al texto como enunciado producido, y en tanto tal como "mimesis", y que lee en el texto lo que en él se representa o se figurativiza, y no la "otra" enunciación, la que escapa a los límites, coacciones, represiones del azar y la violencia: la que engendra el propio discurso como dialogismo, como sujeto en proceso, como texto y no obra, y que se lee más allá de la inscripción del padre (Barthes, ¿ Por dónde empezar? 77).

Así, el "narrautor", cuya figura ha sido postulada por numerosas perspectivas críticas en torno a Casa de campo como representación del autor empírico, cuyo acto de escritura se expresaría miméticamente en el proceso de escritura del "narrautor" ficticio, quien sería el propio Donoso; y la novela que escribe, Casa de campo, destruye la falacia metaficcional y enuncia en cambio el ser ficticio del narrador, el carácter también artificial de su discurso, el juego de poder que evidencia, y que dice lo contrario de lo que parecería afirmar. Porque el mismo narrador que enuncia el carácter autónomo, arbitrario y puramente artificial, constructivo, de todos los elementos del discurso, al nombrarse a sí mismo como autor "real", al exponer el carácter artificial del discurso como proveniente exclusivamente de su voluntad constructiva y del acto unívoco de su enunciación, dice del enunciado ficticio como producto de una "realidad" exterior a la obra - la del autor empírico-, deconstruyendo con ello la pretensión de absoluta irrealidad e inverosimilitud del discurso.

El texto se juega entonces en la ironía, los juegos de poder que sustituyen el poder de los padres son también los juegos de poder del discurso, la transgresión se resuelve en repetición y no en diferencia; la jerarquía, los castigos, la violencia, las coacciones de los padres, son repetidos una y otra vez por los personajes del universo ficticio que enfrentarían el poder de ellos, que erigirían sus propias leyes en su ausencia. El artificio no escapa del poder paterno: "La Marquesa Salió a Las Cinco" mimetiza, desde las leyes que pretenden evadirlas, las jerarquías del poder: el artificio de Casa de campo, su ser ficticio, parecería decirnos por último la figura del "narrautor", sólo ha sustituido la ley del referente, de la ilusión de realidad, por otra ley, por otro poder, que es también una ilusión: el poder "autorial". Una noción de ficción mimética es sustituida por otra, un monologismo por otro, una coacción discursiva, un poder, por otro. 
Tal vez de aquí podamos desprender una reflexión que es una de las propuestas fundamentales de la metaficción productiva, narrada ya no desde la ironía sino desde el desgarramiento de una experiencia dolorosa: el anhelo de la ficción por proclamarse como realidad, por ser la realidad, y la imposiblidad del autor del relato de no ser sino también un artificio, un signo, cuyo imposible enraizamiento en el mundo revela, como plantea De Man (240-241), la profunda ironía que lo constituye. La metaficción parecería entonces "estar a punto de caer en la tentación" de ser otra forma de mimesis, como lo sugiere el diálogo del narrador y Silvestre, tentación que ella misma debate irónicamente en su interior.

La ironía se manifiesta en la presentación diegética del productor y del receptor del relato, mediante la cual, como en el trompe l'oeil y "La Marquesa Salió a Las Cinco", la desmitificación es también mistificadora: el discurso aparentemente "otro" no escapa de la semejanza con aquello que quiere negar, y muestra su no omnipotencia en la autonomía de los personajes, en la conflictiva polisemia del texto, y en la imagen del lector que éste construye, la cual contradice la visión del lector como receptor de las explicitaciones poéticas, que quieren ser mise en abyme de origen, del texto y del código, y harían de la propuesta metaficcional una decodificación de carácter unívoco del relato.

En Casa de campo el discurso del "narrautor", que aspira a desmitificar el discurso realista y mostrar la autonomía ficcional del discurso novelesco, se torna un discurso irónico que disfraza su propio carácter artificial, sígnico, y pretende otra mistificación: la supresión del azar, del caos, para imponer la voluntad de verdad, de revelación, de solución del enigma; imponer un orden que será deconstruido por la carnavalización del propio relato, su juego interdiscursivo, su tensión entre orden y caos, su desmitificación de la dicotomía realidad/ apariencia, y, en definitiva, erigirse ya no como obra producida por una voluntad constructiva depositaria de la verdad, sino como texto, como metaficción productiva, como sujeto en proceso.

La expectativa decodificadora que el enunciado del "narrautor" promete, genera en la productividad metaficcional lo que Genette llamó casilleros vacíos, que se sustentan en la expectativa frustrada del lector, y "son tan significativos como la presencia explícita y articulada de un elemento discursivo" (Lo verosimil 32), en este caso el "narrautor", cuyos enunciados forman parte del proceso de significancia textual.

La ironía se muestra también en la tensión permanente de lo verosímil con lo inverosímil; la constitución de lo inverosímil tiene como correlato la verosimilitud. Así, por ejemplo, en cuanto al tiempo transcurrido desde la partida de los padres se oponen doce meses a doce horas, y la desnaturalización de las convenciones temporo-espaciales puede constituirse en instrumento para el ejercicio de la represión desde el poder del propio discurso: bastaría con mencionar la muerte de los hijos de Cordelia, ya que si el tiempo se ha desnaturalizado y sólo ha transcurrido un día, es imposible que "sea un bebé de verdad", es sólo un juego más. El discurso de lo inverosímil se confronta con lo verosímil, y su no adecuación, su desnaturalización, su no ley, es instrumento para el ejercicio de la represión y de la violencia desde el poder del discurso.

Problemática que es una constante en la producción narrativa de Donoso, porque si el texto se lee sin la inscripción del padre, en cambio todo autor lleva la inscripción de su obra. Por ello, para Barthes, el autor se inscribe en el texto, pero 
... su inscripción no es ya privilegiada, sino lúdica: se convierte, por así decirlo, en un autor de papel: su vida ya no es el origen de sus fábulas, sino una fábula concurrente con su obra: hay una reversión de la obra sobre la vida (y no el caso contrario); es la obra de Proust, de Genet, lo que permite leer su vida como un texto (Barthes, ¿Por dónde empezar? 77).

Así, los términos se invierten, es el texto el que produce la imagen del autor, no el autor el que "produce" el texto-de ahí que Donoso diga que El obsceno pájaro lo escribió a él: todo texto escribe a su autor desde su muerte como sujeto de la enunciación.

\section{EL OBSCIENO PÁJARO DE LA NOCHE: LA RIZOMÁTICA PRODUCTIVIDAD SIGNIFICANTE}

La metaficción productiva se interroga a sí misma — como Edipo- pero ello no la convierte en "una máscara que se señala con el dedo" (Barthes, Ensayos críticos 128). Ella se muestra como "artificio", pero no se limita a señalarnos que un yo ficticio narra el relato, o que los personajes son una construcción del lenguaje: la metaficción productiva desnaturaliza el lenguaje, y en él desnaturaliza las convenciones estéticas e ideológicas, diciéndonos mediante qué cortes, qué transformaciones, cuáles destrucciones, deseos e incertidumbres es posible ser ficción, cómo es posible que ello acontezca, qué debate es necesario llevar a cabo en el cuerpo de su escritura, quiénes son sus agentes, qué acaece con el discurso, con el autor, con el lector, qué construcciones y deconstrucciones la engendran como caos productor de significancia, como carnaval y como rizoma.

En el diálogo intertextual que la metaficción productiva teje con algunas de las proposiciones más sugestivas - desafiantes, deconstructivas - de la contemporaneidad, nuestro metatexto quiere explicitar su profunda relación con la imagen de rizoma que propone Deleuze (Rizoma) y que nos fuera sugerida por el propio Donoso cuando habla de la génesis, significado y desarrollo de El obsceno pájaro de la noche:

No hay una intención de significado preciso.

Es una novela cuyo desarrollo no ha sido lineal, ni planeado.

Ha sido algo así como un "happening", algo que me ha ido sucediendo, que me ha ido matando a mí y que yo he ido matando, que yo he ido desgajando a trozos de mí, ramas que le han crecido por acá, y ramas por allá, una cosa viva. Es algo que me ha ido sucediendo más bien que he escrito (Rodríguez Monegal 518).

En una oportunidad Roa Bastos escribió que el autor es el único que no puede "genuinamente" señalar "las fuentes de significancia" de su propia obra,

... primero, porque la escritura y el habla no son órdenes complementarios ni análogos; segundo, porque los códigos de explicación que utilizará serán necesariamente diferentes y opuestos a los que desarrolló el proceso de construcción textual (167-168).

Este enunciado, que reafirma nuestra visión del problema del "narrautor" en Casa de campo en la necesaria concepción del texto como productividad, se constituye en sí mismo en una propuesta sobre el discurso ficticio: sobre el dialogismo escritura/oralidad, autor/texto, y su percepción como productora de significancia. Lucidez "autorial" que sólo es sobrepasada 
por la "lucidez poética" de su discurso metaficcional: Yo el Supremo (Gaspar La lucidez poética).

Como Roa Bastos, y seguramente por similares preocupaciones, Donoso - a diferencia del "narrautor" con el cual se le ha querido identificar- elude "explicar" o "interpretar" de manera unívoca su discurso, tal vez porque éste es un rizoma, el cual "no puede ser atribuido, ni sometido a ningún significante, cualquiera que sea" (Deleuze 25). Pero ambos enunciados —el "autorial" y el textual- se dicen a sí mismos en la elusividad, en la ambigüedad. Y en ese entretejido discursivo que es la productividad metaficcional —un rizoma que "pone en juego regímenes de signos muy diferentes" (Deleuze 50) - las imágenes de Donoso juegan especularmente con las imágenes — también rizomáticas, también múltiples- del rizoma de Deleuze, las que refractan a su vez, "prismáticamente", las imágenes que hemos ido dibujando en torno a la metaficción productiva y que nuestro metatexto quiere hacer dialogar.

La metaficción productiva es un rizoma porque un rizoma es una multiplicidad, pero "lo múltiplehay que hacerlo", noesuna esencia sino una producción que descentra el logocentrismo de la cultura occidental, lo que Derrida llama su "metafísica", porque "ya no tiene ninguna relación con el Uno como sujeto o como objeto, como realidad natural o espiritual, como imagen y mundo" (Deleuze 18).

Carente, como planteara Donoso, de un significado preciso, de un plan previo atribuible a su "genealogía", y de un desarrollo lineal, el rizoma es una extraordinaria imagen del sujeto en proceso que es toda metaficción productiva, sujeto caótico y descentrado que se nombra a sí mismo en "este crecimiento de las dimensiones en una multiplicidad que cambia de naturaleza a medida que aumenta sus conexiones", y cuyas entradas y salidas son múltiples porque posee simultáneamente "líneas de segmentariedad, desde las cuales es estratificado, significado, atribuido, etc; pero también líneas de desterritorialización por las que se escapa sin cesar" (Deleuze 19-24), líneas que se remiten unas a otras descentradamente.

El rizoma es una imagen reflexiva de la realidad, el sujeto, la creación estética, que establece su diferencia en relación al árbol y a la raíz en tanto "sistemas", "composiciones". Para Deleuze los "sistemas arborescentes" son "sistemas jerárquicos que comprenden centros de significancia y subjetivación", y constituyen la imagen del logocentrismo de la cultura occidental, que se concibe a sí misma como "árbol-mundo", cuya falsa multiplicidad sólo puede limitarse a crear el "libro-raíz".

El proceso de las "ramas" de Donoso ha sido interpretado como la no "objetivación" del escritor frente a su novela - El obsceno pájaro de la noche - en un sentido coincidente a la visión del narrador de Casa de campo como "escritor" de la novela. Para nosotros, en cambio, una vez más, el signo es precisamente el inverso del que propone esta lectura: las "ramas" de Donoso, - “tallos subterráneos", "tubérculos": rizomas, en palabras de Deleuze — son esa "cosa viva", aquello que sucede mientras ellas se multiplican y crecen en diferentes direcciones, en continuos descentramientos, porque la metaficción productiva, como el rizoma, es un sistema acentrado.

Las ramas - "que me han ido matando"- desgajadas del uno, del sujeto de enunciación, son una extraordinaria imagen de su proceso y de la escritura en la alteridad realidad/ficción, verosimilitud/productividad, obra/texto, que narra la metaficción productiva. Y son también, para nosotros, el reconocimiento de nuestra percepción de ella como ajena a todo espejo reproductor, a cualquier repetición —-mismidad, en términos de Foucault—aun de aquélla que 
se establecería entre texto y metatexto, en la cual "el Uno se convierte en dos" para autocontemplarse, y no para producirse como multiplicidad, para generarse como diferencia en el descentramiento y la deconstrucción denuestro aparentemente irreductible logocentrismo.

Desde esta perspectiva, El obsceno pájaro de la noche puede ser leída como una metaficción de la metaficción productiva: ella narra cómo una "obra", un "libro-mundo", un "libro-raíz", se torna en rizoma, desde la transformación y muerte de los sujetos de la enunciación, de su monstrificación en el caos de la productividad significante. Ficción del nacimiento de un discurso en la herida, la exclusión, la constitución de la dicotomía alteridad/ ficción y la clausura de la realidad para generar una diferencia que hará rizoma con el mundo.

La rizomática ficción del nacimiento tiene en El obsceno pájaro de la noche su mise en abyme de fundación en el gesto del cacique, que elide la "realidad" y genera una ficción que, como Casa de campo, pone en escena el discurso del poder y el poder en el discurso.

El discurso fundacional es el autoritario y encubridor del cacique, quien oculta con su poncho lo caótico y lo obsceno, el azar y la no-legalidad, lo no normado, y coloca en la escena textual una ficción monológica, ordenada y controlable. Su discurso se refractará en el de Jerónimo, quien lo imprime, ajeno al devenir de los signos y a la esencial estructura caótica del universo, en el medallón heráldico de piedra. En una clara refracción especular, en la cual la leyenda se torna mise en abyme de la ficción, Jerónimo precisa, para la consolidación de su discurso, ejercer la "exclusión": eliminar a la Peta Ponce - la nana buena de Inés/la bruja poderosa - con la "autoridad" que le confiere ser el sujeto de la enunciación - "la autoridad de su silencio la eliminaba" - lo azaroso, lo irracional, lo oscuro, lo plural: el rumor y el desorden del discurso, arroparlo con el manto de su enunciación.

Jerónimo es el "autor omnisciente", el "autor-Dios" que genera el "discurso teocrático" (Britto García). Con sólo desearlo podría inscribir para siempre en piedra, sin interferencias ni ambigüedades, una historia configurada linealmente, la de Inés y Jerónimo, proyecto que deberá escamotear del relato el discurso que es su alteridad, recubrir ideológicamente el discurso de lo oscuro, lo bajo e irreverente, el discurso del carnaval. Ha de preservar las jerarquías y el orden del universo, desterrándolo no sólo de su vida, sino también a otro espacio físico: a la Casa.

Así, la oposición Casa/Rinconada se nos presenta ya no como dialógica, en el sentido bajtiano, sino como el ejercicio del poder de exclusión del discurso del poder, que escinde el universo en una dicotomía. Lo uno y lo otro se muestran como dos formas de lo mismo: el uno y el mismo, es el "Uno que se convierte en dos"(Deleuze 11), que en su dicotomía garantiza la separación y la exclusión. Es, en el discurso de Jerónimo, el modelo occidental del "árbol" que la metaficción productiva desentroniza:

... el modelo del libro y del pensamiento: el logos, el filósofo-rey, la trascendencia de la idea, la interioridad del concepto, la república de los espíritus, el tribunal de la razón, los funcionarios del pensamiento, el hombre legislador y sujeto. Pretensión del Estado de ser la imagen interiorizada del orden del mundo, y de enraizar al hombre (Deleuze 58-59).

La dicotomía de la pareja perfecta y la pareja oscura, cada una en su espacio, preservaba el orden y la transparencia del discurso perfecto que unívocamente crearía un hijo perfecto, su "mimesis", su "raicilla": 
Todo estaba dispuesto. Jerónimo había logrado por fin sacar a Inés del medallón estático de la dicha conyugal perfecta: ayudada por su mano galante la conduce para tomar las actitudes prescritas en el siguiente medallón, en que figurarían como padres. Mientras la Peta y yo, seres fantásticos, monstruos grotescos, cumplíamos con nuestra misión de sostener simétricamente desde el exterior ese nuevo medallón como un par de suntuosos animales heráldicos (El obsceno pájaro de la noche 228).

Pero el discurso de la metaficción productiva anhela escapar al poder, y de la relación especular entre ambos espacios, la Casa y la Rinconada, se genera Boy: una línea de fuga, un movimiento de desterritorialización (Deleuze 8-9). El discurso de la ficción es rizomático, genera su propio rumor, y su juego de espejos no es reproducción, ciega, mimética refracción: es creación, transformación: monstrificación de lo normado, de la ley del uno y lo mismo, de las identidades y las semejanzas(Foucault, Las palabras y las cosas); la ficción desterritorializa lo territorializado, lo priva de "raíz". Jerónimo engendra a Boy, un hijo producto de descentramientos sucesivos, un "otro" cuyo signo es la diferencia: el signo de la ficción:

Pero cuando Jerónimo entreabrió por fin las cortinas de la cuna para contemplar al vástago tan esperado, quiso matarlo ahí mismo: ese repugnante cuerpo sarmentoso retorciéndose sobre su joroba, ese rostro abierto en un surco brutal donde labios, paladar y nariz desnudaban la obscenidad de huesos y tejidos en una incoherencia de rasgos rojizos ... era la confusión, el desorden, una forma distinta pero peor de la muerte (228-229, énfasis mío).

Tras el primer impulso de aniquilarlo porque era imagen de todo lo que escindió de su vida, Jerónimo repite una vez más el gesto enunciador del cacique: encubre la realidad, la "imbuncha" del afuera y la transforma. De esta manera, de la oposición entre la Casa y la Rinconada, se crea un nuevo espacio ficticio: esta vez lo desechado, lo que debe ser negado, ocultado, no se disocia a otro ámbito, sino que un espacio ficticio se metamorfosea en otro para hacer posible la ficción: de la primera Rinconada se "edifica" la Rinconada para Boy.

El procedimiento que genera la nueva ficción es mise en abyme del movimiento del discurso de El obsceno pájaro de la noche: el referente de realidad - la existencia de Boyes silenciado por la coacción del discurso, por la autoridad de su enunciador, quien "contribuyó con su silencio a borrar todas las sombras de lo que para él debe haber sido una tragedia" (232). La elisión genera un vacío, el cual será tratado de "colmar" por Jerónimo, quien "coloca" a Boy en el centro del relato y construye para él una cosmogonía con leyes propias: Jerónimo crea un discurso ficticio. Y como todos los discursos ficticios generados en El obsceno pájaro de la noche, cuyos espacios representados y espacios de enunciación son la Casa y la Rinconada, la nueva Rinconada será también un gran imbunche que imbunchará a Boy, quien a su vez es un imbunche, imbunches que son mise en abyme del gran imbunchamiento textual.

El encierro de Boy es el encierro del caos de la metaficción productiva, el esfuerzo por tornar lo rizomático en árbol-raíz: la pugna entre el orden y el caos de discurso y "realidad" que la metaficción pone en escena:

... the traditional supremacy of order over disorder is negated in chaotic systems and in metafiction, and the hierarchy is neutralized to a dialogue between the two which generates the patterns of the natural world and of the text (Stoicheff 93). 
Boy es en sí mismo una extraordinaria mise en abyme, hiperbolizada, de la metaficción productiva como cuerpo textual, como organismo vivo: en la monstruosidad de Boy acontecen para la ley del "orden" y de la identidad "estallidos de las referencias, de las luces del saber, golpes más sordos, más penetrantes, venidos de "la otra escena" (Barthes, La narratología hoy 175).

Venidos de esa diferencia que es la ficción, de ahí que Boy es lo "anormal" y todos los monstruos que lo rodean son lasúnicas figuras ficticias que si bien sustituibles en sus funciones, no lo serán en cuanto a los atributos que les son propios; cada uno de ellos se diferencia de los demás.

Boy es un texto cuyos rasgos "desnudaban la obscenidad de huesos y tejidos" (229), un texto que muestra su heterogeneidad y multiplicidad, el dibujo de sus tejidos, la obscenidad de su no-ley, el escándalo de su refutación a la lógica y al orden: espacio de la arbitrariedad y la inconclusión: del cuerpo de la escritura.

Pero el discurso de la "monstruosidad" — de la diferencia - es, en palabras de Donoso, "la destrucción de 'patterns' de vida, de esquemas de comportamiento; significa la necesidad de volver a construir mil cosas", y "causa horribles angustias y horribles dolores" (Rodríguez Monegal 525), y es, sobre todo, un desafío al discurso del poder. Por ello la confusión, el desorden, el caos, lo obsceno, lo irracional, lo "otro" que anida en el ser humano y en el mundo, ha de ser enmascarado. El procedimiento se centra ya no, como en la leyenda, en el sujeto mismo, sino en sus atributos, en su diferencia: en la monstruosidad de Boy. Mediante un singular proceso de ideologización, se le sublima, se le otorga una jerarquía de nobleza con lo cual se le intenta equiparar con la perfección e insumir en la "mismidad". Así, lo monstruoso deja de ser persecutorio y para Jerónimo en "la Rinconada (...) paseó un amor tan perfecto que sólo pudo producir a un ser magnífico como Boy” (235).

No obstante, ello no es suficiente. Se lleva a cabo entonces la gran fantasía, el hiperbólico proyecto de la creación ficticia: hacer desaparecer toda dicotomía. No sólo transformar lo "anormal" en "norma", sino suprimir todo parámetro de relación con el mundo: construir un nuevo "orden", una realidad enteramente artificial, realidad ficticia sin alteridad alguna, ella misma sujeto y objeto, ella misma la anulación del deseo y la consumación de todo deseo: un discurso narcisista y logocéntrico - "él era principio y fin y centro de esa cosmogonía creada especialmente para él" (235)- en el cual el sujeto sería el fundante del universo que existiría únicamente como proyección de sí mismo, universo que es un discurso cuyas "palabras" carecerán de clave y de significación:

... Boy debía crecer con la certeza de que las cosas iban naciendo a medida que su mirada se fijaba en ellas y que al dejar de mirarlas las cosas morían, no eran más que esa corteza percibida por sus ojos, otras formas de nacer y de morir no existían, tanto, que principales entre las palabras que Boy jamás iba a conocer eran todas las que designaban origen y fin. Nada de porqués, ni cuándos, de afueras, de adentros, de antes, de después, de partir, de llegar, nada de sistemas ni generalizaciones. (...) Boy debía vivir en un presente hechizado, en el limbo del accidente, de la circunstancia particular, en el aislamiento del objeto y el momento sin clave ni significación que pudiera llegar a someterlo a una regla y al someterlo, proyectarlo a ese vacío infinito y sin respuesta que Boy debía ignorar (243). 
El poncho paternal traza un espacio físico en donde Boy será la única norma, y se le rodea de capas concéntricas de monstruos - una galería, un laberinto- que lo protege de toda interferencia del afuera. En el adentro encierra al caos, privándolo de la diferencia que es su esencia al transformarla en norma y única ley universal.

Jerónimo produce un mundo con su personaje principal y sus personajes secundarios, con una noción de espacio, de tiempo, de sujeto y de objeto, de realidad, que deconstruye, como El obsceno pájaro de la noche, la verosimilitud semántica y sintáctica. De esta manera, para enmascarar lo monstruoso, la ficción se ha tornado monstruosa, también ella hiperbólica, de ahí que metaficcionalmente el proceso máximo de imbunchamiento de la ficción se exprese en el universo de los monstruos.

Pero en la metaficción productiva la autorreflexividad, el imbunchamiento, conducen a la proliferación, al clausurar el afuera el espacio interior se agranda y carnavaliza. En la semiosis ilimitada la ficción se monstrifica, recupera para sí los volúmenes, el desorden, los estallidos, las interferencias del cuerpo de Boy, y cada uno de los biseles del prisma metaficcional es descentrado: la metaficción no es nunca un "centro" que devela el enigma textual.

Decíamos que Boy es, como figura, el hijo de Jerónimo, la monstruosidad frente a la belleza y perfección que éste representa, pero el movimiento sígnico del relato propone simultáneamente que Boy es el esperado hijo de Inésy de Jerónimo/del Gigante/de Romualdo / del Mudito / de Brígida / creación del vapor de las ollas de las brujas. Es el hijo de Inés y de Jerónimo, de Inés y de Humberto, de Peta Ponce y de Humberto, de Jerónimo e Iris. Pero Boy nunca llegó a nacer, porque el vientre de Inés, al igual que el de Iris, es estéril, es un imbunche que contiene sólo un vacío, por eso, para el hijo que no tuvo, Inés crea otro imbunche: el "baúlmundo" para Boy. Y todos estos orígenes asumen que el Boy real o "inventado" dentro de la ficción, es monstruoso, sin embargo, el monstruoso es Jerónimo, como lo revelará la escena de su ahogo en el estanque de la Rinconada, y en París sus amigos lo llaman Boy (173), de manera que Boy es Jerónimo. Y Boy es también el Mudito, en la secuencia de la Comisaría.

Las dos figuras enunciadoras cuyo proyecto es el árbol-raíz, Jerónimo y Humberto, generan de sí a otros enunciadores, a otros artífices de la ficción: a Boy y a Mudito. La figura del sujeto de la enunciación se torna también plural, rizomática, descentrada, recusando en la productividad textual todo logocentrismo.

La simultaneidad de orígenes de Boy y la monstrificación de Jerónimo, de Humberto y del Mudito, son fundamentales en la propuesta metaficcional del texto ficticio como un entrecruzado heterogéneo de voces, como una estereofonía y no una genealogía.

Concepciones que proponen otro status del discurso ficticio y descentran nuestras nociones teóricas y críticas, son la materia que nutre el relato metaficcional de El obsceno pájaro de la noche, que, como Casa de campo, no se limita a "desnudar" su carácter de artificio verbal en oposición a la falacia mimética del discurso natural, sino que narra la problematización interna que lo constituye —contradictoriamente, rizomáticamente - desde la transformación de los sujetos de la enunciación - Jerónimo, Humberto, Mudito- y sus proyectos en monstruos: en esa productividad significante que es el texto, puesta en escena por la metaficción productiva en el cuerpo caótico, rizomático y carnavalizado de su escritura. 


\section{BiBLIOGRAFÍA CITADA}

\section{TEXTOS DE FICCIÓN}

Borges, Jorge Luis. Obras completas (1923-1973). Buenos Aires: Emecé, 1974.

Britto García, Luis. Abrapalabra. Caracas: Monte Ávila, 1980. Rajatabla. México: Siglo XXI, 1971.

Donoso, José. La desesperanza. Barcelona: Seix Barral, 1986. El obsceno pájaro de la noche. 1970. Barcelona: Seix Barral, 1985. Casa de campo. 1978. Barcelona: Seix Barral, 1983. El jardin de al lado. Barcelona: Seix Barral, 1981.

\section{DE FUNDAMENTACIÓN TEÓRICA}

Bajtín, Mijail. La cultura popular en la Edad Mediay Renacimiento. Barcelona: Seix Barral, 1974.

Barthes, Roland. "Análisis textual de un cuento de Edgar Poe". La narratología hoy. Prada Oropeza, comp. La Habana: Arte y Literatura, 1984. ¿Por dónde empezar? Barcelona: Du Seuil y Tusquets Editor, 1974. Ensayos críticos. Barcelona: Seix Barral, 1973.

Britto García, Luis. "Joyce, la muerte de (El Autor) Dios". Suplemento Cultural de Últimas Noticias (Caracas, 26 de agosto de 1984): 8-9.

Cerda, Carlos. José Donoso: originales y metáforas. Santiago: Planeta Chilena, 1988.

Dällenbach, Lucien. Elrelatoespecular. Madrid: Visor, 1991 (en francés: Le recitspéculaire. París: Seuil, 1977).

De Man, Paul. Visión y ceguera: Ensayos sobre la retórica de la crítica contemporánea. Puerto Rico: Editorial de la Universidad de Puerto Rico, 1991.

Deleuze, Gilles y Félix Guattari. Rizoma. Valencia: Pre-Textos, 1977.

Eco, Umberto. Obra abierta. Barcelona: Ariel, 1979. La estructura ausente. Introducción a la semiótica. Barcelona: Lumen, 1978.

Foucault, Michel. El orden del discurso. Barcelona: Tusquets, 1970. Las palabras y las cosas. México: Siglo XXI, 1968.

Gaspar, Catalina. Escritura y metaficción. Caracas: Casa de Bello, en prensa, 1996. - El universo en la palabra. Lectura estético-ideológica de Abrapalabra de Britto García. Colección Estudios, Monografias y Ensayos, 171. Caracas: Academia Nacional de la Historia, 1996. La lucidez poética. Cuadernos de Difusión, 187. Caracas: Fundarte, 1991.

Genette, Gérard. Figuras III. Barcelona: Lumen, 1989. "La escritura liberadora: lo verosímil en la Jerusalén Liberada del Tasso". Loverosímil. Buenos Aires: Tiempo Contemporáneo, 1972. 31-61.

GutiérrezMouat, Ricardo. José Donoso: imposturae impostación. Gaithersburg: Hispamérica $1,1983$.

Hayles, Katherine. La evolución del caos. El orden dentro del desorden en las ciencias contemporáneas. Barcelona: Gedisa, 1993. 
Hutcheon, Linda. Narcissistic Narrative. The Metafictional Paradox. New York and London: Methuen, 1984.

Kristeva, Julia. Semiótica 1 y 2. Madrid: Fundamentos, 1981. El texto de la novela. Barcelona: Lumen, 1981.

Lewis, Thomas. "Hacia una teoría del referente literario". Carlos Pacheco, trad. Texto Crítico Año VIII, 26-27 (México, enero-diciembre, 1983): 3-31.

Lyotard, Jean-Francois. La condición postmoderna. Madrid: Cátedra, 1987.

Macherey, Pierre. Para una teoría de la producción literaria. Caracas: Edic. Biblioteca Universidad Central de Venezuela, 1974.

Roa Bastos, Augusto. "Algunos núcleos generadores de un texto narrativo". Escritura Año II, 4, (Caracas, julio-diciembre, 1977): 167-193.

Rodríguez Monegal, Emir. "José Donoso: la novela como Happening” (entrevista sobre El obsceno pájaro de la noche). Revista Iberoamericana, $75-77$ (julio-diciembre 1971): 517-537.

Stoicheff, Peter. "The chaos of Metafiction". Chaos and Order: Complex Dynamics in Literature and Science. Katherine Hayles, ed. Chicago: The University of Chicago Press, 1991.

Vargas Llosa, Mario. La verdad de las mentiras. Colombia: Seix Barral, 1991. 
